\title{
An Empirical Study on Career Choices Among Undergraduates: A PLS-SEM Hierarchical Component Model (HCM) Approach
}

\author{
Siew Chin Wong (corresponding author) \\ Faculty of Business, Economics and Accounting and Economic \\ HELP University, 50490 Kuala Lumpur, Malaysia \\ E-mail: sc.wong@help.edu.my
}

Jia Ying Lim

Faculty of Business, Economics and Accounting and Economic

HELP University, 50490 Kuala Lumpur, Malaysia

E-mail: ying950627@gmail.com

\section{Chui Seong Lim}

Faculty of Business, Economics and Accounting and Economic

HELP University, 50490 Kuala Lumpur, Malaysia

E-mail: chuiseong.lim@help.edu.my

\section{Kay Tze Hong}

Faculty of Business, Economics and Accounting and Economic

HELP University, 50490 Kuala Lumpur, Malaysia

E-mail: kaytze@help.edu.my

Received: April 18, 2019 Accepted: May 15, 2019 Online published: May 27, 2019

doi:10.5296/ijhrs.v9i2.14841 URL: https://doi.org/10.5296/ijhrs.v9i2.14841 


\section{Abstract}

This study examines how undergraduates' personality, parental and peer influences on their career choice. Partial Least Square, hierarchical component model (HCM) was used to measure the formative measurement model of personality construct and reflective measurement models of parent and peer influence constructs on career choices in the study. Data were collected from 218 of undergraduates from local private and public universities. Findings show that there are significant positive relationship between personality, parental and peer influences and career choices. Such insights are useful for HRD practitioners to develop relevant HRD interventions to assist individuals and organizations in career development. Limitations and suggestions for future research are also discussed.

Keywords: career choices, undergraduates, personality, parental and peer influence

\section{Introduction}

The landscape for career development is changing. Globalisation, new technologies, demographic changes, and the emergence of new occupations are important for career choice and development (Reitman and Schneer, 2003). In the past few years, there has been growing interest in the career choices of undergraduates and recent graduates. Making difficult career choices are a regular phenomenon and may even be one of the hallmarks of undergraduates. Career choices in different professions/disciplines may lead to the grief that individual college students can't stand, but there is little time to focus on public reflection. Undergraduate students will soon realise the importance of these decisions and develop their own styles to handle these decisions in the years of study. As part of the training program outlined in the tertiary syllabus, there is always a lack of communication, learning and skills to make career choices (Stephen, 2007). Laughland-Booy, Mayall and Skrbis (2015) revealed that personal choice has been prioritised and the individual decides what she or he can do in career development.

Choosing a career is a very important decision that affects the career development process and career success. In Malaysia, Generation Y (Gen Y) accounts for nearly $50 \%$ of the workforce (Malaysia Statistics Bureau, 2017). They are a powerful workforce that affects organisational performance, work style, effectiveness and efficiency. PwC Malaysia (2012) emphasises the work-life balance, the attractiveness of the salary mix and working abroad, as learning opportunities are a major trend in Gen Y's career choices. In this rapidly changing business environment, the labour market is now becoming increasingly uncertain and complex (Wilton, 2011). According to the Malaysian Bureau of Statistics (2017), the youth unemployment rate in Malaysia has risen from 2.8\% in 2014 to 3.5\% in 2016. The Human Resources Department of Malaysia also stated that the number of unemployed graduates in 2015 was 273,600 . In 2015, there were approximately $10.7 \%$ of unemployed youth in Malaysia. Among the unemployed graduates, $15.3 \%$ are higher education graduates and $9.8 \%$ are non-graduates. In addition, the Ministry of Education (MoE) revealed that $27 \%$ of private university graduates and $24 \%$ of public university graduates have been unemployed for six months after graduation in 2015. This indicates that the percentage of unemployed graduates in private universities are higher than that of local public universities. 
According to Ng, Gossett, Chinyoka and Obasi (2016), inappropriate career choice risk is one of the main factors affecting graduate employment opportunities. Therefore, it is important to examine the career choices of local undergraduates in Malaysia to reduce the unemployment rate of future graduates. In addition to unemployment, career choice has always been the focus of attention. The main reasons for the unemployment of graduates are lack of work experience, oversupply in the labour market, poor communication and poor interpersonal skills. Therefore, self-awareness of personality, abilities, skills and interests will increase the advantage in determining their career choices (Ibrahim \& Mahyuddin, 2017).

Previous career pieces of literature have echoed the changes from stable, upward, linear career path to a dynamic, a multi-directional and boundless career path that was motivated by the pursuit of individualistic goals and values (Baruch, 2004). However, there is a lack of research on the career choices of undergraduate students in Malaysia. In particular, there is still a lack of research to prioritise career selection. In addition, career choice has not been adequately studied with relevant research variables. For example, career development (Maimunah \& Lawrence, 2007), career success (Roziah, Maimunah \& Sidek, 2009), career aspirations (Maimunah \& Efizah, 2010), career aspiration (Maimunah \& Hoo, 2014), protean career (Wong and Roziah, 2015). In other words, empirical pieces of evidence on some of the contextual variables that may be relevant to career choices are still insufficient (Maimunah \& Efizah, 2010; Chan \& Ong, 2014). The purpose of this study was to examine the factors that influenced the career choices of undergraduates in response to the Wong and Quek (2015), who emphasised the need to examine different career models of generational differences. As such, this study makes a unique contribution to enriching career-related pieces of literature, particularly to use a hierarchical component model (HCM) approach to measure a formative measurement of the construct of personality (Hair, Sarstedt, Ringle, \& Gudegan, 2018).

\section{Literatures Review}

\subsection{Career Choice}

The process of responding to the unique challenges of job hunting and employment transformation is called career choice. Career choices can provide a socially acceptable way for adolescents to directly or indirectly satisfying their motivations, which may be strong, but not fully satisfied early in their development (Baloch, 2016). The Social Cognitive Career Theory (SCCT) model considers the importance of individual characteristics in the career decision process. This model focuses on the interrelationship between personal, behavioural and environmental variables (Lent, Brown and Hackett, 1994). In addition, Lent \& Brown (2006) suggested in the SCCT model that individuals are more likely to take action and be responsible for achieving their career goals if they have access to environmental resources and support such as parental support and peer group support. Given the growing body of empirical evidence supporting SCCTS in explaining career-related topics, its use should be considered in determining the predictors that influence an individual's career choice (Hall, 2002).

A career is defined as a personal trajectory in the working life of an individual, in the field of work, and in the position that an individual begins until the end of working life. It is related 
to the continuous development of individuals in a particular field of work while being active in a particular sector and gathering relevant skills and experience to achieve career growth (Ates, 2016). Therefore, careers seem to be an important part of people's lives because they can improve the individual social status, living standards, and relationships with others. Choosing a career is a daunting task that anyone has to face, as it will either shape or destroy a person's future, as there are several vocations or career options to choose from (Egunjobi, Salisu \& Ogunkeye, 2013). People who always maintain a steady state of mind and choose the careers they are passionate about (i.e., self-interest), follow their parents' preferred careers, careers that open up their education to them, the availability of learning opportunities, and the need for self-fulfilment also affects the career choices of individuals (Ates, 2016). Earlier references emphasised that the main intrinsic factors that influence career choice are self-concept, interest, personality type, attitudes and cultural identity. The external dimensions include role models, social interaction and availability of resources. These resources include ethnicity, information and finances, education and work attributes (Ates, 2016). In the current study, personality, parental influence, and peer influence are the three independent variables that affect the dependent variable (i.e., career choice).

\subsection{Personality}

Personality traits are one of the elements of "personal input" in the SCCT model. It shows that "personal input" is essential for deciding the career of an individual, as it can facilitate the exercise of an agency, such as personal control within career management and career development (Lent, Brown and Hackett, 1994). For example, Barrick, Mount \& Gupta (2003) pointed out that there are personality traits that predict the success of jobs and others that are related to certain occupations. The Five-Factor Model (FFM) of personality is used in the current study because of its stability, validity, and universality, which characterises the personality dimension, is established as the model most commonly used in empirical studies (Gunkel, Schlaegel, Langella \& Peluchette, 2010). FFM was also known as the Big Five model. There are five dimensions of personality traits in FFM, namely extraversion, agreeableness, emotional stability, conscientiousness, and openness (Digman, 1990).

The dimension of extroversions was praised as the first dimension of the five-factor model. The features correlated with this dimension are active, talkative, assertive and sociable. Agreeableness refers to features that are flexible, forgiving, soft-hearted, tolerant, trusting, and cooperative (Goldberg, 1981, McCrae \& Costa, 1985). Emotional stability, also known as neuroticism, is the degree to which one adjusts, calms, is safe, and empathises. Emotionally stable individuals are well placed to deal with stress, are able to deal with criticism, and generally do not make mistakes or failures. He or she usually builds positive relationships and can improve relationships between others (McCrae \& Costa, 1985). Openness to the experience includes traits such as cleverness, imaginativeness, curiosity, artistic sensitivity and broad mind. Finally, conscientiousness dimension includes diligence, being organised, responsible, cautious and thorough (McCrae \& Costa, 1985).

Personality traits are also defined as a person's behaviour and response to the environment. An individual's success in his career requires a trait. For example, certain occupations may 
require specific characteristics related to job attributes to meet the job requirements (Youshan \& Hassan, 2015). Career success depends to a large extent on the compatibility between job characteristics and job personality traits. Personality will have a major impact on a person's career direction and goals, as individuals attempt to match his/her characteristics and interests to possible work (Witt, Burke-Smalley, Barrick, \& Mount, 2002; Hussain, Abbas, Shahzad and Bukhari; 2012).

Turban, Stevens, and Lee (2009) found that conscientiousness and extroversion are useful predictors of undergraduates who are looking for and obtaining employment after graduation. Individuals with a high degree of responsibility and extroverted personality traits are active and responsible, and employ multiple approaches to obtain employment. Hussain et al., (2012) added that emotional stability, agreeableness, extraversion, openness to experience and conscientiousness dimensions will involve certain vocational behaviours such as occupational interest, career decision-making and job satisfaction, career self-exploration, career information seeking, career search self-efficacy. Although FFM is the most common measure of personality in empirical research, career choices for undergraduate students in the context of higher education institutions in Malaysia have not been extensively studied. Therefore, FFM was used as a personality measure in this study. Specifically, Hierarchical Component Model (HCM) approach was used to identify the significance of each personality dimensions on undergraduates' career choices.

\subsection{Parental Influence}

Parents are considered to be the main drivers of the child's socialisation process, in which children's behaviour, attitudes and social skills are important in determining a child's career choice (Maimunah \& Roziah, 2006). Compared to important figures such as teachers and friends, Parental figures seem to have a greater impact on the child's initial career development. Parents have the responsibility to equip and maintain a favourable family learning environment to encourage their early active learning behaviour. Encouraged by parents, individuals realise that parents provide a favourable learning environment for their intellectual development, academic aspirations and career goal achievement (Maimunah \& Roziah, 2006). Kniveton (2004) supports that parents to have the greatest impact on student career choices. The motivational influence of parental role models, such as managing hard life, inspiration and achievement, has been instilled as a value for children who can demonstrate the same behaviour when making career choice decisions (Maimunah \& Roziah, 2006). Conversely, some parents are aware of this impact, but still believe that they have little impact on their child's career choices (Taylor, Harris \& Taylor, 2004). Parents and students have different opinions because students always explain that their parents have the greatest impact on their future career choices from a young age (Ferry, 2006; Kniveton, 2004).

In addition, Werner and DeSimone (2006)'s career model development phase supports individuals' early recognition of specific attitudes through the effects of growing the background and growth stages of the environment. Specific development tasks occur, such as focusing on the future, increasing personal control over career choices, and obtaining appropriate work habits and attitudes. When it comes to the exploratory stage of life, the 
occupational choice of an individual's designated professional identity is strongly influenced by parents (Roziah \& Maimunah, 2006). Therefore, the profession and occupation of parents and socioeconomic also play an important role in the career choices that affect children's future (Hewitt, 2010; Saleem, Hanan, Saleem, \& Shamshad, 2014). At the level of education that parents receive, children are more likely to receive parental support and resources when making career decisions. Kumar (2016) also revealed that students with a deep understanding of parental careers and their career styles are more likely to be important in influencing students' career choices. However, some parents always make career choices on behalf of their children. Whether in the same status category or in a higher status category. For example, as a parent who is a teacher, he/she will encourage his/her child to enter the field like him/her. Similarly, a skilled worker can encourage his/her child to follow his/her footsteps or urge them to find other occupations with better compensation and benefits (Saleem et al., 2014).

Udoh and Sanni (2012) conducted a study of 200 students from 11 public high schools. They found a significant relationship between the educational background of parents and the career choices of children. The study found that $61.2 \%$ of students strongly agreed with their parents' educational background and influenced their career choices. Similarly, Orlando (2010) conducted a survey of 320 respondents studying in Liberia with the aim of examining factors affecting undergraduate career choices. The survey results show that $65 \%$ of students make career choices based on their parents' expectations rather than on their/her interests. Therefore, in this study, it is important to consider parental influence as an integral part of the contextual impact as an independent variable.

\subsection{Peer Influence}

As suggested by the SCCT, although individual responsibility is a key element of individual career management, peer influence as a contextual factor always affects an individual's career choices and decisions (Hall, 2002). Peers and friends have a major impact on the individual's well-being and social adaptation and have been confirmed by developmental psychologists. Building relationships through networking can be seen as a key factor influencing career choices (Forret and Dougherty, 2004; Hashim \& Embong, 2015). Adolescents and young adults are vulnerable to group norms because they develop personal identities and behaviours that meet the normative expectations of their peers. Most teenagers and young people spend $29 \%$ of their waking hours interacting with friends and sharing their thoughts and ideas (Hashim \& Embong, 2015). They get information, opinions and verbal encouragement from friends and peers to choose a career. Peer support is an important factor in helping individuals face career indecision problem. Bandura (2004) also explained that when individuals are encouraged and motivated by others, they can successfully complete tasks. Therefore, this support will enhance the individual's self-efficacy beliefs, especially exploring career choices (Tan \&Laswad, 2006; Calkins \& Welki, 2006).

In this context, it is critical that undergraduates build social and interpersonal relationships and networking with peers. Social relationships are developed through the association of members via academic functions and additional curriculum activities. This form of 
interaction is further enhanced by regular meetings and discussions with peers in a variety of topical discussions, collaborative assignments/projects, sports events and workshops, enabling undergraduates to access information and encourage their career choices (Maimunah $\&$ Roziah, 2006). They argue that interaction via academic functions brings benefits in terms of developing new skills and good practices, a better social network and improved communication skills, which are useful in helping them make a career choice decision (Wong \& Quek, 2015). With emotional support and advice from friends, it is easier to facilitate a person's commitment to managing their career.

Lindholm, Astin, Sax and Korn (2002) explained that the socialisation process can influence career inspiration and career choice preferences among undergraduates. It should be noted that graduates rely on the social influence of information or word-of-mouth communication with their peers to make decisions about job choices. Van Hoye and Lievens (2009) revealed that this social influence of information had a significant impact on undergraduates' perception of occupational attractiveness. The particularly positive word of mouth peer reviews affects the job application process and career choices of the individual (Van Hoye \& Lievens, 2009). For example, when a friend accompanying a person to a job fair and considering a job in an organisation is attractive, that person was also influenced by a friend and to consider the occupation as attractive and to be considered a future career choice (Van Hoye and Saks 2010). As a result, peer influence is considered as an important independent variable in this research.

Based on the review of the existing pieces of literature, we have made the following hypothesis:

H1: There is a positive relationship between personality and career choices among undergraduates.

$\mathrm{H} 2$ : There is a positive relationship between parental influences and career choices among undergraduate students.

H3: There is a positive relationship between peer influence and career choice among undergraduates.

\section{Methodology}

\subsection{Population and Sample}

The sampling units are undergraduates from local and private universities in Malaysia. Respondents come from different faculties and project studies such as science, business, engineering, law, hotel management, information technology and others. In this study, a convenience sampling method was used because undergraduates were target respondents with the aim of interacting and collecting the required information (Leedy \& Ormrod, 2013). A total of 218 completed questionnaires was received in this study.

The current study involves $46.8 \%$ of male and $53.2 \%$ of female undergraduates. The number of respondents in public and private universities was 116 and 102 respectively. Overall, $32.6 \%$ of respondents were from business, economics and accounting courses, $21.1 \%$ were 
from engineering and science, and $13.3 \%$ and $10.1 \%$ were from hotel management and information technology courses. At the same time, $5 \%$ of respondents were from the Faculty of Law and $17.9 \%$ were from other courses/faculties. Instrumentation and goodness of measurement of the constructs in terms of their validity and reliability are discussed in the following sections.

\subsection{Instrumentation}

All instruments were adopted from established instruments and were adapted to measure study variables. The five-point Likert scale has been applied to all instruments.

\subsubsection{Career Choice}

The seven-item scale was adapted according to the choice of the Career Questionnaire (CCQ) (Olamide \& Olawaiye, 2013). All items were measured using a 5 point Likert-like scale with values $1=$ "strongly disagree" to $5=$ "strongly agree". Examples of items are "I definitely made a career choice." And "I will choose my career choice based on my interest in a particular occupation".

\subsubsection{Personality Traits}

Goldberg's International Personality Item Pool (IPIP) (Goldberg, 1999) was used to assess the Big Five personality. The measurement of behavioural traits is associated with the five dimensions of personality, namely extraversion, conscientiousness, agreeableness, emotional stability, and openness to experience. Each dimension was measured with a 5-point Likert scale: 1 = "never" to 5 = "very often". The sample question was "I feel comfortable with people" and "I make people feel comfortable".

\subsubsection{Parental Influence}

The Parental Career Behaviour Checklist (PCBC) was used to measure this variable (Keller and Whiston, 2008). PCBC consisted of twenty-three items assessing participants' perceptions of general parenting behaviours (support scale) and career-specific parenting behaviours (action scale). However, nine questions have been adopted and adapted in this section. All items were measured using a 5 point Likert-like scale with values $1=$ "strongly disagree" to 5 = "strongly agree". Sample questions were "My parent gives an opinion when I have difficulty choosing a career".

\subsubsection{Peer Influence}

The Peer Group Influence Assessment Questionnaire (PGIAQ) was used to measure the influence of the current peer study (Ezzarrouki, 2016). It consists of fifteen items measured on a 5-point Likert scale with $1=$ "strongly disagree" to $5=$ "strongly agree". However, eight questions have been adopted and adapted to this section, such as "My peers motivate me to make a career decision in advance" and "I will ask my friends for help when I have a problem". 


\subsection{Data Analysis}

Smart PLS software (version 3.2.7) was used for data analysis due to the low requirements for data distribution, sample size and measurement scales. In addition, this study was exploratory in nature. The Hierarchical Component Model (HCM) was used in this study, which allows researchers to reduce the number of relationships in the structural model, thereby making the PLS path model more parsimonious and easier to grasp (Hair et al., 2018). As a rule, a reflective-formative HCM has been applied to personality constructs in order to examine the importance of five personality dimensions influencing career choices in this study. The five different dimensions (conscientiousness, extraversion, agreeable, emotional stability and openness to experience) that represent lower-order-constructs (LOCs) of the more general HOC (personality). PLS-SEM has an advantage in the HCM specification because it allows a combination of reflective and formative in the same model (Becker, Klein $\&$ Wetzels, 2012). The research framework included both reflective and formative measures. The reflective measurement model was evaluated using both a convergent and discriminant validity analysis. The factor loadings, the composite reliability and the average variance extracted (AVE) were used to examine the convergent validity. However, the multicollinearity between the indicators and the significance and relevance of the outer weight of each formative indicator were used to evaluate the formative measurement model. In this context, the variance inflation factor (VIF) and the t-value were determined (Hair et al., 2018).

\subsection{Common Method Bias}

In addition, since this study employed the same group of respondents (undergraduates) and a five-point Likert scale to measure each item of the questionnaire, a common method bias could, therefore, appear in this study (Podsakoff, MacKenzie, Lee and Podsakoff, 2003). Hence, the presence of the common method bias was evaluated using a consistent PLS algorithm with a factorial weighting scheme and a maximum iteration of 300. The results indicated that the VIF values of all constructs were less than 3.3 indicating that there is no common method bias in the structural model (Hair et al., 2018).

\subsection{Convergent Validity}

\subsubsection{Reflective Measures}

Convergent validity is the degree to which a set of indicators (items) that are supposed to measure a construct correspond to the theories (Hair, Black, Babin, Anderson and Tatham, 2017). It represents the strength of the relationship between the items that are supposed to represent a single latent construct. Based on Hair, Hult, Ringle and Sarstedt (2017), factor loading, composite reliability, and the average variance extracted (AVE) (i.e., the sum of squared loadings divided by the number of indicators) were used to examine the convergent validity of the reflective model. As shown in Table 1, loadings for all items were above the recommended value of 0.7 (Hair et al., 2010). The composite reliability indicates that latent constructs ranged from 0.834 to 0.892 , which exceeds the recommended value of 0.7 (Hair et al., 2017). Subsequently, the AVE (to measure the variance captured by the indicators relative to the measurement error) of the respective constructs was greater than the recommended 
value of 0.5 (Hair et al., 2017). Therefore, this study achieves the convergent validity requirement for reflective measures.

Table 1. Result of measurement model

\begin{tabular}{|c|c|c|c|c|}
\hline First order constructs & Item & Loadings & $\mathrm{CR}$ & AVE \\
\hline \multirow[t]{4}{*}{ Career choice } & $\mathrm{C} 1$ & 0.715 & 0.834 & 0.557 \\
\hline & $\mathrm{C} 4$ & 0.752 & & \\
\hline & C6 & 0.772 & & \\
\hline & $\mathrm{C} 7$ & 0.746 & & \\
\hline \multirow[t]{5}{*}{ Peer influence } & PE4 & 0.698 & 0.876 & 0.587 \\
\hline & PE5 & 0.705 & & \\
\hline & PE6 & 0.859 & & \\
\hline & PE7 & 0.747 & & \\
\hline & PE8 & 0.808 & & \\
\hline \multirow[t]{5}{*}{ Parent } & $\mathrm{F} 1$ & 0.796 & 0.892 & 0.624 \\
\hline & $\mathrm{F} 2$ & 0.839 & & \\
\hline & F3 & 0.762 & & \\
\hline & $\mathrm{F} 4$ & 0.837 & & \\
\hline & F6 & 0.707 & & \\
\hline \multirow[t]{4}{*}{ Agreeableness } & P10 & 0.771 & 0.828 & 0.546 \\
\hline & P7 & 0.753 & & \\
\hline & P8 & 0.767 & & \\
\hline & P9 & 0.660 & & \\
\hline \multirow[t]{3}{*}{ Conscientiousness } & $\mathrm{P} 13$ & 0.697 & 0.824 & 0.611 \\
\hline & P14 & 0.824 & & \\
\hline & P16 & 0.816 & & \\
\hline \multirow[t]{3}{*}{ Emotional Stability } & P17 & 0.818 & 0.762 & 0.528 \\
\hline & P18 & 0.500 & & \\
\hline & P19 & 0.815 & & \\
\hline \multirow[t]{3}{*}{ Extraversion } & $\mathrm{P} 2$ & 0.765 & 0.858 & 0.669 \\
\hline & P3 & 0.816 & & \\
\hline & P5 & 0.870 & & \\
\hline \multirow[t]{4}{*}{ Openness } & $\mathrm{P} 23$ & 0.816 & 0.882 & 0.651 \\
\hline & P24 & 0.821 & & \\
\hline & $\mathrm{P} 25$ & 0.804 & & \\
\hline & $\mathrm{P} 26$ & 0.785 & & \\
\hline
\end{tabular}




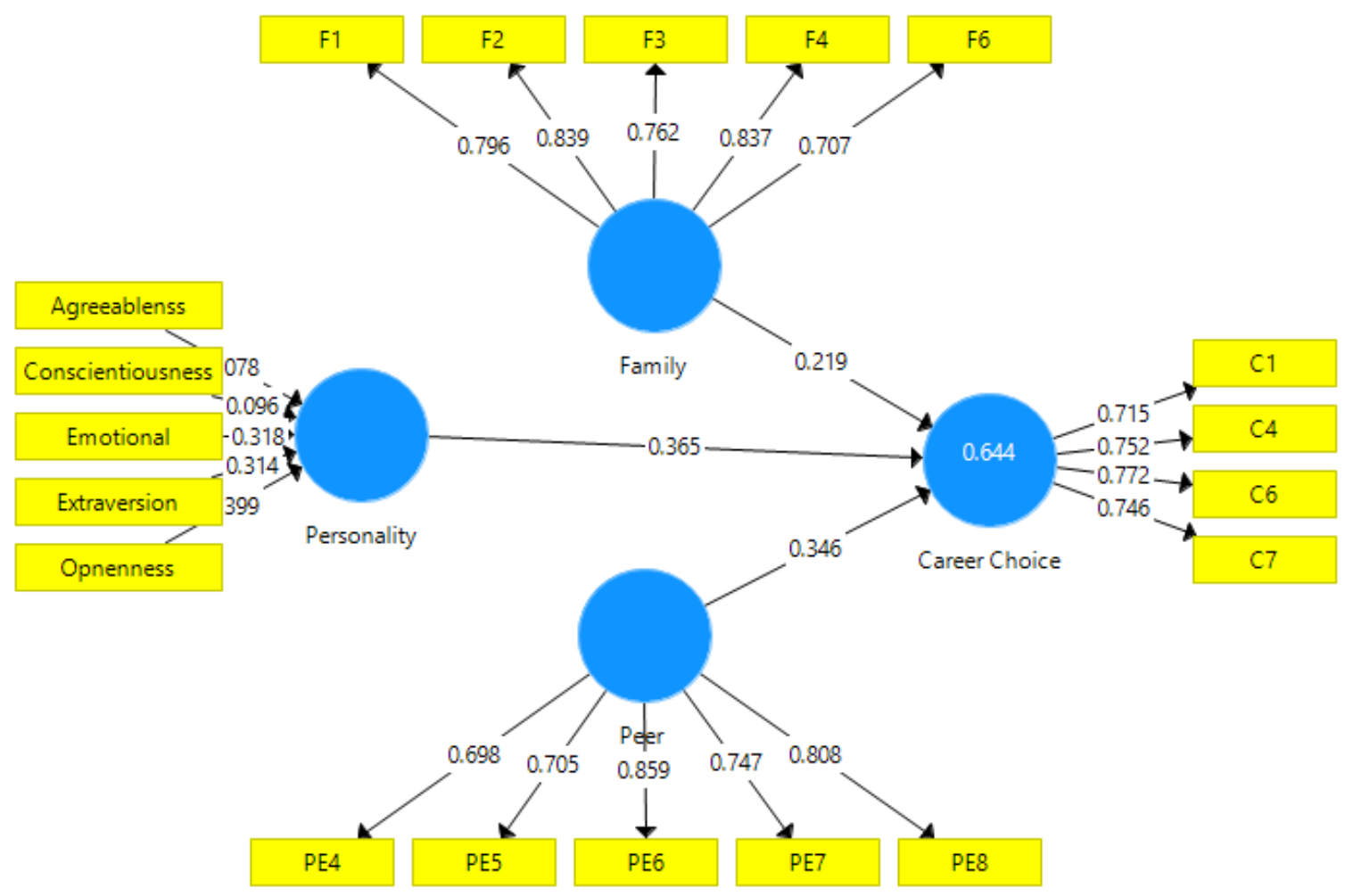

Figure 1. Result of Path Analysis (Structural Model)
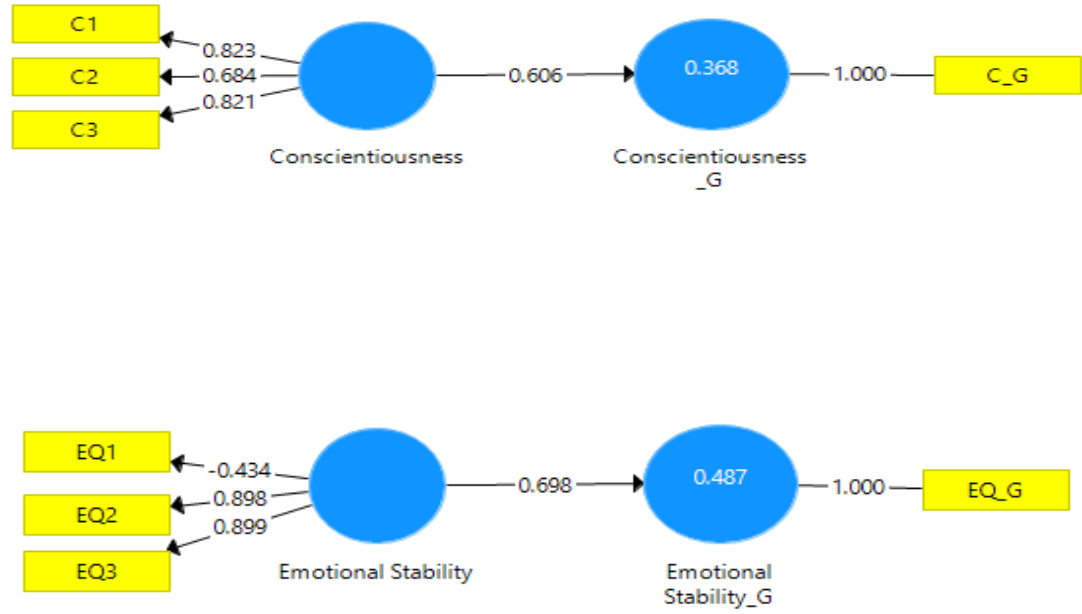

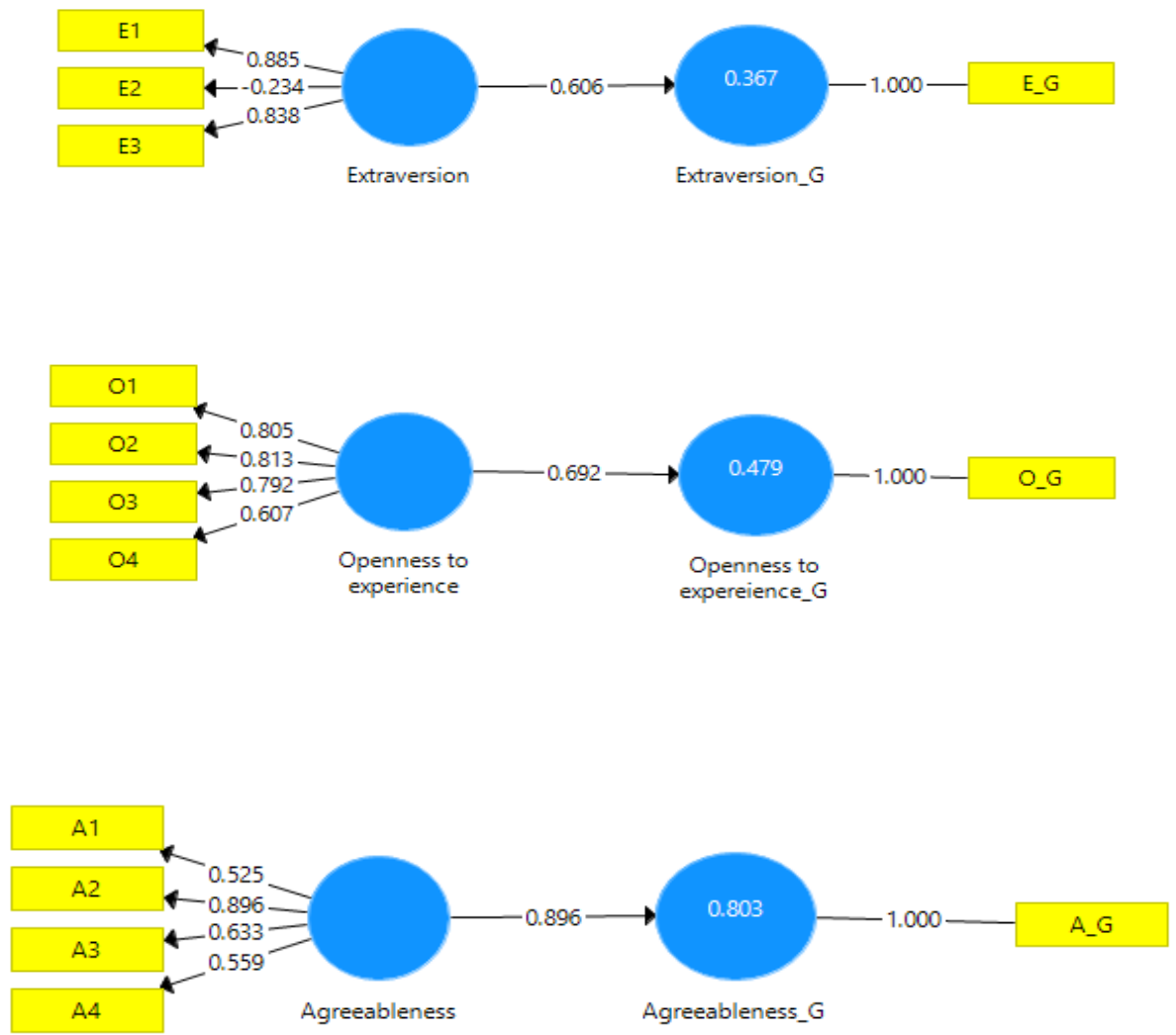

Figure 2. Redundancy Analysis

\subsubsection{Discriminant Validity}

Discriminant validity explains to what extent a construct really differs from other constructs. As shown in Table 2, the correlations for each construct were less than the square root of AVE for the indicators measuring this particular construct, indicating the sufficient discriminant validity (Hair et al., 2017). In addition, the Heterotrait-Monotrait criteria (HTMT) was used to determine the ratio of the between-traits correlations to the within-traits correlations. If the constructs in the path model are conceptually more distinct, a conservative threshold of 0.85 seems appropriate (Henseler, Ringle, and Sarstedt, 2016). In Table 3, all heterotrait-monotrait (HTMT) values (Henseler et al., 2016) for the current study are significantly lower than the more conservative value of the threshold of 0.85 (Kline, 2011). This indicates that discriminant validity has been established. In general, the measurement model in the present study shows sufficient convergent and discriminant validity. 


\section{Al Macrothink}

International Journal of Human Resource Studies

ISSN 2162-3058

2019, Vol. 9, No. 2

Table 2. Discriminant Validity (Fornell and Larcker Criterion)

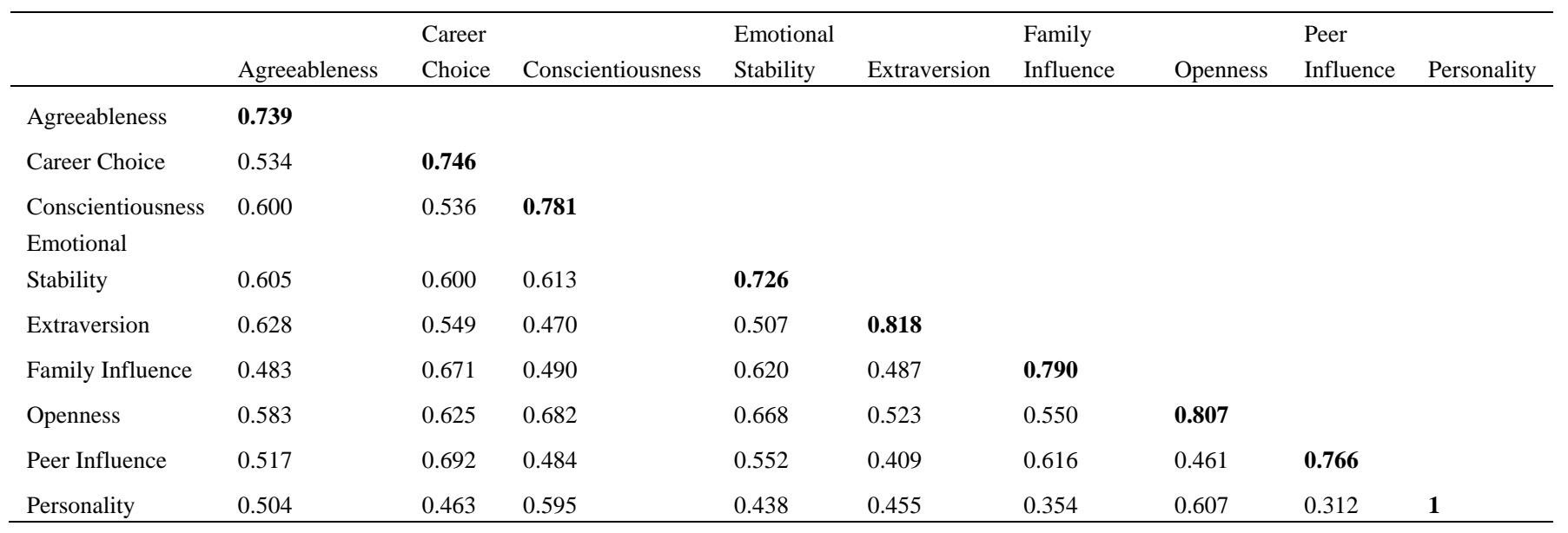

Note: Diagonals represent the square root of the AVE while the off-diagonals represent the correlations

Table 3. HTMT Criterion

\begin{tabular}{|c|c|c|c|c|c|c|c|c|c|}
\hline & Agreeableness & $\begin{array}{l}\text { Career } \\
\text { Choice }\end{array}$ & Conscientiousness & $\begin{array}{l}\text { Emotional } \\
\text { Stability }\end{array}$ & Extraversion & $\begin{array}{c}\text { Parent } \\
\text { Influence }\end{array}$ & Openness & $\begin{array}{c}\text { Peer } \\
\text { Influence }\end{array}$ & Personality \\
\hline \multicolumn{10}{|l|}{ Agreeableness } \\
\hline Career Choice & 0.732 & & & & & & & & \\
\hline Conscientiousness & 0.865 & 0.767 & & & & & & & \\
\hline Emotional Stability & 0.991 & 0.968 & 1.052 & & & & & & \\
\hline Extraversion & 0.852 & 0.741 & 0.639 & 0.807 & & & & & \\
\hline Parent Influence & 0.614 & 0.835 & 0.647 & 0.908 & 0.571 & & & & \\
\hline Openness & 0.757 & 0.813 & 0.915 & 1.013 & 0.650 & 0.649 & & & \\
\hline Peer Influence & 0.667 & 0.874 & 0.654 & 0.854 & 0.526 & 0.725 & 0.556 & & \\
\hline Personality & 0.590 & 0.542 & 0.721 & 0.610 & 0.492 & 0.387 & 0.664 & 0.343 & \\
\hline
\end{tabular}

Criteria: Discriminant validity is established at HTMT 0.85 (Kline, 2011)

\subsection{Assessment of Formative Second Order Construct}

Table 4 describes the evaluation of the formative second-order construct. With respect to the formative model, the result of the redundancy analysis of the path coefficients is 0.6 and above, which presents a satisfactory level of convergent validity for an exploratory study in Figure 2 (Hair et al., 2017). This study is exploratory in nature to examine the five different dimensions of personality in order to influence the career choices of undergraduates. In addition, the multicollinearity between the indicators is evaluated. Based on the results presented in Table 4, all formative construct indicators satisfy the VIF values and are consistently below the threshold value of 5 (Hair et al., 2017) and also at 3.3 (Diamantopoulos and Siguaw, 2016). Therefore, it can be concluded that collinearity does not reach critical levels in any of the formative constructs and is not a problem of estimating the 


\section{MInstitute ${ }_{\text {Int" }}^{\text {Macrothink }}$}

International Journal of Human Resource Studies

ISSN 2162-3058

2019, Vol. 9, No. 2

PLS path model. Finally, the significance and relevance of the outer weights of the formative constructs are examined. The result shows that all formative indicators are significant, with the exception of agreeableness and conscientiousness. However, previous research or theory provides evidence for the relevance of these indicators to capture the operational definition of personality (Digman, 1990). As a result, these indicators are retained in the formative concept even if their outer weights are not significant.

\subsection{Assessment of Structural Model}

Before evaluating the structural model, it is essential to ensure that there is no lateral collinearity problem with the inner model of the study. Table 5 shows the results of the lateral colinearity test of the model. All inner VIF values for each construct are below threshold value 3.3 (Diamantopoulous \& Siguaw, 2006), which means that lateral multicollinearity is not a concern in this study.

Table 6 and Figure 1 shows the results of the PLS output. The $\mathrm{R}^{2}$ value showed that $64.4 \%$ of the variance in career choice were due to the influence of family and peers as well as personality. Further analysis shows that the influence of the parents $(\beta=0.219, p<0.01)$; Peer influence $(\beta=0.346, p<0.01)$ and personality $(\beta=0.365, \mathrm{p}<0.01)$ were positively related to career choice. Therefore, all H1, H2 and H3 were supported. An in-depth study outlined that contextual elements such as peer and personality were key determinants of undergraduates' choice compared to parental influences.

Predictive relevance $\left(\mathrm{Q}^{2}\right)$ is then evaluated to study the predictive power of exogenous constructs over endogenous constructs. $\mathrm{A} \mathrm{Q}^{2}$ value greater than 0 means that the exogenous constructs have the predictive capability on the endogenous constructs (Hair, et al., 2017). In this study, the $\mathrm{Q}^{2}$ value of career choice $(0.212)$, greater than 0 , indicates that the model has sufficient predictive relevance. Finally, the size of the effect $\left(f^{2}\right)$ is aimed at determining whether an exogenous construct has an essential influence on an endogenous construct based on its unique variance and not on its shared variance (Hair et al., 2010). Table 6 presents the effect sizes of the exogenous variables on the endogenous variable, where parental influence $\left(f^{2}=0.065\right)$ has a small effect size on career choices. On the other hand, the influence of the peers $\left(f^{2}=0.191\right)$ and of the personality $\left(f^{2}=0.197\right)$. Both have a medium effect size on career choices. This explains that the influence of personality and peers is more important than parental influences in explaining the career choices of undergraduates.

Table 4. Measurement properties for formative constructs

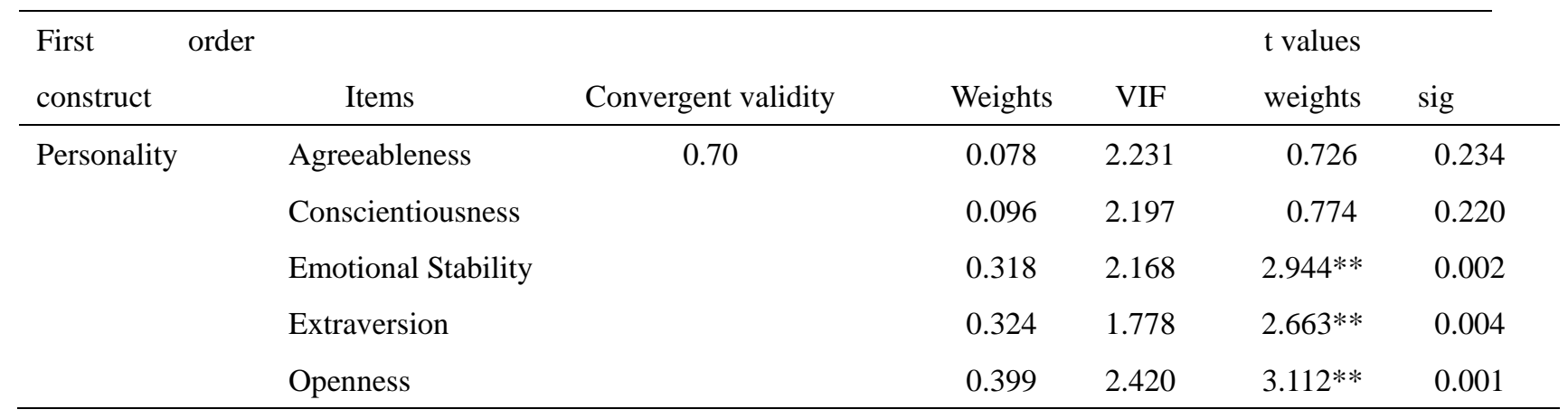


Note: $>1.96^{* *}$

Table 5. Collinearity Assessment

\begin{tabular}{lc}
\hline & Career Choice \\
\hline Parent & 2.055 \\
Peer & 1.756 \\
Personality & 1.907 \\
\hline
\end{tabular}

Table 6. Path Co-efficient Assessment

\begin{tabular}{lllllll} 
Relationship & & & & $\mathrm{p}$ & \\
& Direct Effect $(\beta)$ & Standard Error & $\mathrm{t}$ values & values & $\mathrm{f}^{2}$ & Decision \\
\hline Parent -> Career Choice (H1) & 0.219 & 0.081 & $2.700^{* *}$ & 0.003 & 0.065 & Support \\
Peer -> Career Choice (H2) & 0.346 & 0.088 & $3.909^{* *}$ & 0.000 & 0.191 & Support \\
Personality -> Career Choice (H3) & 0.365 & 0.078 & $4.695^{* *}$ & 0.000 & 0.197 & Support \\
\hline
\end{tabular}

$* * \mathrm{p}<0.01$ (one-tailed)

\section{Discussion}

The present results indicate that there is a significant relationship between personality and career choice of undergraduates. Empirical results were supported by previous studies that identified personality traits as important in determining career choices (Hussain et al., 2012; Kemboi, Kindiki and Misigo, 2016). The present study revealed that personality awareness and expectations are associated with the future career choice of many undergraduates. Increased self-awareness of their personality is more likely to achieve success and career goals by seeking appropriate career choices. Undergraduates must always carry out continuous assessment and self-assessment to better understand their future occupations/jobs and their long-term career development throughout the secondary and higher education process. Hall and Las (2010) considered jobs as building blocks of the career. The term career and employment are related to the work/occupation of an individual. They also suggested that a career is a sequence of jobs or positions held by an employee during a given period. This is the continuation of specialisation in a profession despite job changes. Careers are always influenced by the job choices people make over time (Hall \& Las, 2010). Individuals always have a greater personal investment in their work to succeed in their career. They evaluate their performance by advancing within the expected work.

Personality dispositions that allow employees to critical psychological states are related to beneficial work outcomes, including job satisfaction and career development. The process of self-exploration, reflection and evaluation of their personality allows them to examine the underlying values and expectations according to their abilities and personality. People who understand their personality tend to choose career options that reflect their main career 
interests. In particular, specific career goals, develop an intermediate link between interest and career choices. In this context, personality is considered a precursor of interest (Lent et al., 1994). For example, people with low levels of emotional stability may underestimate their ability to manage assigned activities/tasks and distort the effect of perceived competence on career choice. This negative effect is induced in an emotional state and affects their self-efficacy in identifying career choices. In contrast, emotionally stable individuals are well placed to deal with stress, are able to deal with criticism, and generally do not make mistakes or failures, especially when making wrong career choices.

Similarly, individuals with a high degree of extraversion are more sociable, open-minded, gregarious, and experience positive emotions and other sources of information. In addition, the characteristics of dominance and the ability to take control would influence the choice of career. In addition, individuals with a high degree of openness to personal experience may have a flexible and inquisitive opportunity to explore available career choices. They have a wide range of interests and are imaginative, creative and ready to consider new ideas when determining future career choices. Therefore, undergraduates who have a good understanding of their personality are more determined and adaptable in career choice and career advancement. (Gunkel et al., 2010).

Similarly, the present study showed that there is a positive, significant correlation between parent influence and undergraduates' career choice. Parents are very concerned about the future career development of their children as they are still young. They always influence or support their children in determining their career interests and choices by sharing experiences and making suggestions (Salami, 2006). Parental involvement and interaction in the career plan of children by giving their children information about the type of work they want to pursue. It also includes the extent to which parents give encouragement, responsiveness, consent and financial support to their children's career choices. In particular, they devoted their time and dedication to ensuring that their children have a bright future (Salami, 2006). Natalie (2016) pointed out that highly educated parents are more likely to provide their children with job-related information and recommendations, which in turn would affect their choice of career and their interest at an earlier stage (i.e., at the primary/secondary level).

Previous literatures also advocated that children may not choose careers based on their own interests or choices, but rather on the family tradition and expectations of parents. The younger generation feels bound by their responsibilities to continue the family tradition and fulfil the wishes of the older generation (e.g., parent) (Salami, 2006, Wong \& Liu, 2010). Children with a good understanding of their parents' profession and excellent achievement are more likely to follow their parents' footsteps, which ultimately influences their future career choices (Kumar, 2016).

It is noteworthy to explain that peer influence has played an important role in deciding on the career choice of an individual as undergraduates are able to obtain job-related information, opinions and encouragement from their friends and colleagues. For example, undergraduates spend most of their time with peers and friends at the university to complete their academic assignments and participate in additional curriculum activities (Chen, Jones, Scarlata \& Stone, 
2012). The socially supportive environment not only promotes teamwork and collaboration but also paves the way for individual career development. Social support is an important catalyst in the success of a nascent career choice that can play a remarkable role in mobilising resources, identifying opportunities, tacit knowledge, and technical information needed to start a business or a career (Farooq, 2018). Therefore, the social network peer support is accredited considerably for the establishment of a pool of basic resources/input for a career choice decision (Wong \& Quek, 2015; Farooq, 2018). Firstly, emotional support from peers is a sense of caring and a warming sense of positive recognition through the social network that is perceived along with the recognition of others. Emotional support is important to enhance individual's self-esteem in order to pursue desirable career choices (Taylor, 2011).

Secondly, career choice decisions desperately need support from their social network (Farooq, 2018). The information support as a way of getting knowledgeable advice and suggestions at all times. Wong \& Quek (2015) have indicated that information support is valuable information and advice. In difficult decision-making situations, individuals tend to seek suggestions and advice from their closer social network (Farooq, 2018).

\section{Implications}

As individuals are the masters of their career choice management, undergraduates should develop a strong sense of self-confidence and understanding of their own personality traits, strengths and weaknesses that would help them to use the right and optimal approach and different attitudes toward their career choices than others. Employers could also benefit from the results of this study. Information on how individuals approach career planning and careers based on different personality traits is helpful to organisations, particularly in hiring and selecting employees, employee deployment, and the succession planning process (Gunkel et al., 2010).

In addition, the parent should be encouraged to develop further interest in their children's career plans. They could be more involved in the career decision by providing them with the information, encouragement and resources when needed. However, parents should avoid self-fulling prophecy and over-controlling children's career choices, which will put pressure on children. Moreover, undergraduates should build and maintain a social relationship/network with peers. Peers with different major studies at the university would offer different career choice perspectives. It can reduce the mismatch of a job because colleagues/friends from different backgrounds and expertise can provide useful suggestions and insights on a particular career choice (Hashim \& Embong, 2015). For practices, this means that undergraduates must act proactively to ensure that initiatives that purport to promote social networking through effective social media interaction and interpersonal communication. This study is beneficial for universities in designing their course syllabus/programs that focus on student social interaction and network improvement.

\section{Limitations and Future Suggestions}

The study limitations and suggestions for future research are provided. Firstly, the sample of this study is examined by local private universities. The generalisation of study results may 
be limited. Further studies can be undertaken by involving local universities and vocational schools to improve generalisability. Secondly, this study did not examine demographic variables as factors affecting the choice of career among the undergraduates. It is recommended to consider some demographic variables, such as gender and years of study, to get more comprehensive predictors on career choice predictors. The mediating and moderating effects of these variables should also be considered. In addition, qualitative research could be considered in a future study in which it has the benefits of real-time and adaptability.

\section{Conclusion}

The findings of this study have concluded that personality dimension, parental and peer influences have positive relationships with career choice among undergraduate. Individual should take initiatives to determine career choices with the support and assistance from parents, family and peers. It is suggested that future researchers conduct qualitative research on order to have better understand the career choice decision of undergraduates.

\section{Funding}

This work was supported by the HELP University Internal Research Grant Scheme (IRGS) [grant number: RG17-12-022-1].

\section{References}

Ates, S. S. (2016). The Affecting Factors of Career Start in Institutions of Higher Education: Application with Turkish Aviation Students. Journal of Social Sciences, 2(4), 27-34.

Baloch, M. (2016). The Attitude of Graduate Students towards Choice of Career. Insights in Language Society and Culture, 1(2), 86-107.

Barrick, M. R., \& Mount, M. K. (1991). The big five personality dimensions and job performance: A Meta-Analysis. Personnel Psychology, 44, 1-26. https://doi.org/10.1111/j.1744-6570.1991.tb00688.x

Baruch, Y. (2004). The academic career: a model for future careers in other sectors. Journal of Vocational Behavior, 64, 241-262. https://doi.org/10.1016/j.jvb.2002.11.002

Becker, J. M., Klein, K., \& Wetzels, M. (2012). Hierarchical latent variable mdoels in PLS-SEM: guidelines for using reflective-formative type models. Long Range Planning, 45(5), 359-394. https://doi.org/10.1016/j.lrp.2012.10.001

Calkins, L. N., \& Welki, A. (2006). Factors that influence choice of major: why some students never consider economics. International Journal of Social Economics, 33(8), 547-564. https://doi.org/10.1108/03068290610678707

Chan, W. S., \& Ong, L. D. (2014). Boundaryless Career Attitudes, Employability and Employee Turnover: Perspective from Malaysian Hospitality Industry. Research Journal of Applied Sciences, Engineering and Technology, 7(12), 2516-2523. https://doi.org/10.19026/rjaset.7.561 
Chen, C., Jones, K. T., Scarlata, A. N., \& Stone, D. N. (2012). Does the Holland model of occupational choice (HMOC) perpetuate the Bean counter-Bookkeeper (BB) stereotype of accountants. Critical Perspectives on Accounting, 23(4), 370-389. https://doi.org/10.1016/j.cpa.2011.10.006

Diamantopoulos, A., \& Siguaw J. A. (2006). Formative versus reflective indicators in organizational measure development: A comparison and empirical illustration. British Journal of Management, 17(4), 263-282. https://doi.org/10.1111/j.1467-8551.2006.00500.x

Digman, J. M. (1990). Personality structure: Emergence of the five-factor model. Annual Review of Psychology, 41(1), 417-440. https://doi.org/10.1146/annurev.ps.41.020190.002221

Egunjobi, A. F., Salisu, T. M., \& Ogunkeye, O. (2013). Academic Profile and Career Choice of Fresh Undergraduates of Library and Information Science in a Nigerian University of Education. Annals of Library and Information Studies, 60, 296-303.

Ezzarrouki, A. (2016). Peer influence on academic performance in a collectivistic culture. Educational \& Social psychology. Retrieved from: http://www.enews.ma/en/wp content/uploads/2016/11/Paper-Ezzarrouki-Peer- Influence-Final Draft.pdf

Farooq, M. S. (2018). Modeling the significance of social support and entrepreneurial skills for determining entrepreneurial behaviour of individuals: a structural equation modeling approach. World Journal of Entrepreneurship, Management and Sustainable Development, 14, 1-35. https://doi.org/10.1108/WJEMSD-12-2017-0096

Ferry, N. M. (2006). Factors Influencing Career Choices of Adolescents and Young Adults in Rural Pennsylvania. Journal of Extension, 44(3), 1-6.

Forret, M. L., \& Dougherty, T. W. (2004). Networking behaviors and career outcomes: differences for men and women? Journal of Organizational Behavior, 25, 419-437. https://doi.org/10.1002/job.253

Goldberg, L. R. (1981). Language and individual differences: The search for universals in personality lexicons. In L. Wheeler (Ed.). Review of personality and social psychology, 2, 141-165.

Goldberg, L. R. (1999). An alternative "description of personality": the big-five factor structure. Journal of Personality and Social Psychology, 59(6), 1216-1229. https://doi.org/10.1037/0022-3514.59.6.1216

Gunkel, M., Schlaegel, C., Langella, I. M., \& Peluchette, V. J. (2010). Personality and career decisiveness: An international empirical comparison of business students' career planning. Personnel Review, 39(4), 503-524. https://doi.org/10.1108/00483481011045443

Hair, J. F., Hult, G. T. M., Ringle, C. M., \& Sarstedt, M. (2017). A primer on Partial Least Squares Structural Equation modelling (2nd ed.). Thousand Oaks: Sage. https://doi.org/10.15358/9783800653614

Hair, J. F., Sarstedt, Jr. M., Ringle, C. M., \& Gudegan, S. (2018). Advanced issues in partial 
least squares structural equation modeling (PLS-SEM). California Sage Publications Inc. https://doi.org/10.1007/978-3-319-05542-8_15-1

Hall, D. T. (2002). Careers in and out of organizations. Thousand Oaks, CA: Sage.

Hall, D. T., \& Las, H. M. (2010). Reintegrating job design and career theory: Creating not just good jobs but smart jobs. Journal of Organizational Behavior, 31(2-3), 448-462. https://doi.org/10.1002/job.613

Hashim, H. M., \& Embong, A. M. (2015). Parental and Peer Influence upon Accounting as a Subject and Accountacy as a Career. Journal of Economics, Business and Management, 3(2), 252-256. https://doi.org/10.7763/JOEBM.2015.V3.189

Henseler, J., Ringle, C. M., \& Sarstedt, M. (2016). Testing measurement invariance of composites using partial least squares, International Marketing Review, 33, 405-431. https://doi.org/10.1108/IMR-09-2014-0304

Hussain, S., Abbas, M., Shahzad, K., \& Bukhari, S. A. (2012). Personality and Career Choices. African Journal of Business Management, 6(6), 2255-2260. https://doi.org/10.5897/AJBM11.2064

Ibrahim, D. M., \& Mahyuddin, M. Z. (2017). Youth Unemployment in Malaysia: Developments and Policy Considerations. Annual report 2016, 99-105.

Keller, B. K., \& Whiston, S. C. (2008). The role of parental influences on young adolescents' career development. Journal of Career Assessment, 16, 198-217. https://doi.org/10.1177/1069072707313206

Kemboi, R. J., Kindiki, N., \& Misigo, B. (2016). Relationship between Personality Types and Career Choices of Undergraduate Students: A Case of Moi University, Kenya. Journal of Education and Practice, 7(3), 102-112.

Kline, R. B. (2015). Principle and practice of structural equation modelling. Guilford publications.

Kniveton, B. H. (2004). The Influences and Motivations on Which Students Base Their Choice of Career. Research in Education, 72, 47-59. https://doi.org/10.7227/RIE.72.4

Kumar, S. (2016). Career Choice and College Students: Parental Influence on Career Choice Traditionalism among College Students in Selected Cities in Ethiopia. International Journal of Psychology and Educational Studies, 3(3), 23-30. https://doi.org/10.17220/ijpes.2016.03.003

Laughland-BooÿJ., Mayall, M., \& Skrbis, Z. (2015). Whose choice? Young people, career choices and reflexivity re-examined. Current Sociology, 63(4) 586-603. https://doi.org/10.1177/0011392114540671

Leedy, P., \& Ormrod, J. (2013). Practical Research Planning and Design (11ed.) Upper Saddle River: Prentice-Hall. 


\section{Mll Macrothink}

International Journal of Human Resource Studies ISSN 2162-3058 2019, Vol. 9, No. 2

Lent, R. W., \& Brown, S. D. (2006), Integrating person and situation perspectives on work satisfaction: a social cognitive view. Journal of Vocational Behavior, 45, 79-122. https://doi.org/10.1016/j.jvb.2006.02.006

Lent, R. W., Brown, S. D., \& Hackett, G. (1994). Toward a unifying social cognitive theory of career and academic interest, choice and performance. Journal of Vocational Behavior, 45, 79-122. https://doi.org/10.1006/jvbe.1994.1027

Lindholm, J. A., Astin, A. W., Sax, L. J., \& Korn, W. S. (2002). The American college teacher: National Norms for the 2001 - 2002 HERI faculty survey. Los Angeles: UCLA Higher Education Research Institute.

Maimunah, I., \& Efizah, S. R. (2010). Career Aspirations of R\&D Professionals in Government Research Institutes and Multinational Corporations in Malaysia. Organizations and Markets in Emerging Economies, 1(2), 32-47.

Maimunah, I., \& Hoo, S. L. (2014). Cultural values and career goals of the millennial generation: An integrated conceptual framework. The Journal of International Management Studies, 9(1), 38-49.

Maimunah, I., \& Lawrence, A. (2007). Exploring mentoring as a tool for career advancement of academics in private higher education institutions in Malaysia. The Journal of International Social Research, 1(1), 136-148.

Maimunah, I., \& Roziah, M. D. (2006). High flying academics: A question of career mobility. Kuala Lumpur: Pelanduk.

Malaysia Statistics Bureau. (2017). Labour forces survey report, Malaysia. Retrieved from https://www.dosm.gov.my/v1/index.php?r=column/cthemeByCat\&cat=126\&bul_id=aEdIelhl VTBtOHhjOUxqcXhyc2pCUT09\&menu_id=U3VPMldoYUxzVzFaYmNkWXZteGduZz09

McCrae, R. R., \& Costa, P. T. (1985). The NEO Personality Inventory manual. Odessa, FL: Psychological Assessment Resources.

Ministry of Education. (2015). Malaysia Education Blue Print 2013-2-25. Retrieved from https://www.moe.gov.my/images/KPM/PADU/PADU\%20LAPORAN\%20TAHUNAN\%2020 17\%20ENGLISH.pdf

Natalie, M.F. (2006). Factors influencing career choice of adolescents and young adults in rural Pennsylvania, Journal of Extension, 44(3), 52-65.

Navin, D. S. (2009). Effects of dating and parental attachment on career exploration. USA: University of New Hampshire.

Ng, E. S., Gossett, W. C., Chinyoka, S., \& Obasi, I. (2016). Public vs Private sector employment: An exploratory study of career choice among graduate management student in Botswana. Personnel Review, 45(6), 1367-1385. https://doi.org/10.1108/PR-10-2014-0241

Olamide, S. O., \& Olawaiye, S. O. (2013). The Factors Determining the Choice of Career among Secondary School Students. The International Journal of Engineering and Science, 
2(6), 33-44.

Olando, C. (2010). Counselling needs of adults. Lagos: Joy Press Ltd.

Podsakoff, P. M., MacKenzie, S. B., Lee, J. Y., \& Podsakoff, N. P. (2003). Common method biases in behavioral research: A critical review of the literature and recommended remedies. Journal of Applied Psychology, 88(5), 879-903. https://doi.org/10.1037/0021-9010.88.5.879

PwC, P. (2012). Millennials at Work: Reshaping the Workforce Malaysia. Retrieved from https://www.pwc.com/my/en/assets/publications/millennials-at-work.pdf

Reitman, F., \& Schneer, J. A. (2008). Enabling the new career of 21 st century. Organizational Management Journal, 5, 17-28. https://doi.org/10.1057/omj.2008.4

Roziah, M. R., \& Maimunah, I., \& Sidek, M. N. (2009). Towards developing a theoretical framework for measuring public sector managers' career success. Journal of European Industrial Training, 33(3), 232-254. https://doi.org/10.1108/03090590910950596

Salami, S, O. (2006). Influence of culture, family and individual differences on choice of gender-dominated occupations among female student in tertiary institution. Women in Management Review, 22(8), 650-665. https://doi.org/10.1108/09649420710836326

Saleem, N., Hanan, M. A., Saleem, I., \& Shamshad, R. M. (2014). Career Selection: Role of Parent's Prefession, Mass Media and Personal Choice. Bulletin of Educational and Research, 36(2), 25-37.

Stephen, M. K. (2007). Making Career Choices. Surgical Innovation, 14(1), 65-66. https://doi.org/10.1177/1553350607299715

Tan, L. M., \& Laswad, F. (2006). Students' beliefs, attitudes and intentions to major in accounting. Accounting Education: An International Journal, 15(2), 167-187. https://doi.org/10.1080/09639280600787194

Taylor, J., Harris, M. B., \& Taylor, S. (2004). Parents Have Their Say...About Their College-age Children's Career Decision. NACE Journal, 64(2), 1-5. available at: http://jobweb.com.

Taylor, S. E. (2011). Social support: a review. In Friedman, M.S. (Eds.), The Handbook of Health Psychology (pp. 189-214). New York, NY:Oxford University Press, Inc.

Turban, D. B., Stevens, C. K., \& Lee, F. K. (2009). Effects of Conscientiousness and Extraversion on New Labor Market Entrants' Job Search: The Mediating Role of Metacognitive Activities and Positive Emotions. Personnel Psychology, 62, 553-573. https://doi.org/10.1111/j.1744-6570.2009.01148.x

Udoh, N. A., \& Sanni, K. B. (2012).Parental background variables and the career choice of secondary school students in Uyo local government area, Nigeria. Mediterranean Journal of Social Sciences, 3(1).

Van Hoye, G., \& Lievens, F. (2009). Tapping the grapevine: a closer look at word-of-mouth 
as a recruitment source. Journal of Applied Psychology, 94(2), 341-52. https://doi.org/10.1037/a0014066

Van Hoye, G., \& Saks, A. M. (2010). The instrumental-symbolic framework: organizational image and attractiveness of potential applicants and their companions at a job fair. Applied Psychology: An International Review, 60(2), 311-35. https://doi.org/10.1111/j.1464-0597.2010.00437.x

Werner, J. M., \& DeSimone, R. L. (2006). Human Resource Development (6th ed.). Mason, Ohio: Thomson South-Western.

Wilton, N. (2011). An introduction to human resource management. London: Sage.

Witt, L., Burke-Smalley, L. A., Barrick, M. R., \& Mount, M. K. (2002). The Interactive Effects of Conscientiousness and Agreeableness on Job Performance. Journal of Applied Psychology, 87(1), 164-169. https://doi.org/10.1037/0021-9010.87.1.164

Wong, S. C. K., \& Liu, G. J. (2010). Will parental influences affect career choice?: Evidence from hospitality and tourism management students in China. International Journal of Contemporary Hospitality Management, 22(1), 82-102. https://doi.org/10.1108/09596111011013499

Wong, S. C., \& Quek, L. S. (2015). Factors Affecting Individual Career Management among Undergraduates in Higher Education Institutions. International Journal of Academic Research in Business and Social Sciences, 5(10), 56-68. https://doi.org/10.6007/IJARBSS/v5-i10/1842

Wong, S. C., \& Roziah, M. R. (2015). Protean Career among Professionals in Malaysian Electrical and Electronics Industry and the Moderating Role of Career Strategies. European Journal of Training and Development, 39(5), 1-25. https://doi.org/10.1108/EJTD-02-2015-0009

Youshan, B. B., \& Hassan, Z. (2015). The effect of employee's personality on organizational performance: study on insurance company. Journal of Accounting \& Business Management, 3(1), 187-196. https://doi.org/10.24924/ijabm/2015.04/v3.iss1/187.196

\section{Copyright Disclaimer}

Copyright for this article is retained by the author(s), with first publication rights granted to the journal.

This is an open-access article distributed under the terms and conditions of the Creative Commons Attribution license (http://creativecommons.org/licenses/by/4.0/). 